\title{
Using different satellite imagery and classification techniques to assess the contribution of trees outside forests in the municipality of Maringá, Brazil ${ }^{1}$
}

\author{
Betina Doubrawa², Ana Paula Dalla Corte , Carlos Roberto Sanquetta $^{3}$
}

\begin{abstract}
Forest cover of the Maringá municipality, located in northern Parana State, was mapped in this study. Mapping was carried out by using high-resolution HRC sensor imagery and medium resolution CCD sensor imagery from the CBERS satellite. Images were georeferenced and forest vegetation patches (TOFs - trees outside forests) were classified using two methods of digital classification: reflectance-based or the digital number of each pixel, and object-oriented. The areas of each polygon were calculated, which allowed each polygon to be segregated into size classes. Thematic maps were built from the resulting polygon size classes and summary statistics generated from each size class for each area. It was found that most forest fragments in Maringá were smaller than $500 \mathrm{~m}^{2}$. There was also a difference of $58.44 \%$ in the amount of vegetation between the high-resolution imagery and medium resolution imagery due to the distinct spatial resolution of the sensors. It was concluded that high-resolution geotechnology is essential to provide reliable information on urban greens and forest cover under highly human-perturbed landscapes.
\end{abstract}

Key words: CCD sensor imagery, HRC sensor imagery, mapping, remote sensing, urban greens.

\section{RESUMO}

\section{Uso de diferentes imagens de satélite e técnicas de classificação para avaliar a contribuição de árvores fora das florestas no município de Maringá}

O objetivo deste trabalho foi mapear a área de cobertura florestal no município de Maringá, região norte do Estado do Paraná. Para isso, foram usadas imagens de alta e média resolução do satélite CBERS 2B, sensores HRC e CCD. As imagens foram georreferenciadas e classificadas segundo a vegetação de porte florestal por meio de duas abordagens de classificação digital: uma, baseada nos números digitais ou refletância dos pixels e, outra, classificação orientada ao objeto. Foram calculados os números e áreas dos polígonos, sendo os mesmos separados em classes de tamanho de áreas. Foram construídos mapas temáticos, apontando as classes de tamanho dos fragmentos florestais, e sumarizadas as áreas de cada uma das classes. Verificou-se que o maior número de fragmentos florestais do município de Maringá encontra-se na classe menor que $500 \mathrm{~m}^{2}$, ressaltando a importância que os pequenos maciços florestais (TOFs - trees outside the forest) têm na paisagem. Verificou-se uma diferença de 58,44\% de área verde, encontrada nas imagens de alta resolução espacial, em relação à de média resolução espacial. Este resultado denota a importância de se utilizar geotecnologias com maior resolução espacial, na detecção de TOFs, em pequenos verdes urbanos e áreas com elevado grau de antropização.

Palavras-chave: imagem CCD, imagem HRC, mapeamento, sensoriamento remoto, verdes urbanos.

\footnotetext{
Received: 14/08/2012; Accepted: 17/05/2013.

${ }^{1}$ This research was supported by $\mathrm{CNPq} / \mathrm{Peld}$ Sitio 9 .

2 Forest Engineer. Departamento de Ciências Florestais, Universidade Federal do Paraná, Campus III, Avenida Lothário Meissner, 900, Jardim Botânico, 80210-170, Curitiba, Paraná, Brasil. betaaa_d@yahoo.com.br

${ }^{3}$ Forest Engineers, Doctors of Science. Departamento de Ciências Florestais, Universidade Federal do Paraná, Campus III, Avenida Lothário Meissner, 900, Jardim Botânico, 80210-170, Curitiba, Paraná, Brasil. anacorte@ufpr.br (corresponding author); sanquetta@ufpr.br
}

Rev. Ceres, Viçosa, v. 60, n.4, p. 480-488, jul/ago, 2013 


\section{INTRODUCTION}

The mapping of forest cover and its dynamics has become the object of study of many researchers nowadays. The UN Food and Agricultural Organization published an overview of global forest cover in 2011 (FAO, 2011) and South America still had the highest rate of forest area loss, with 4 million hectares per year, followed by Africa, which lost 3.4 million per year. The Brazilian Ministry of Environment released in 2007 the results of its Biome Land Cover Map, part of the Conservation and Sustainable Use of Diversity Project MMA/PROBIO (2007), which gave an overview of the country's remaining forests and the Atlantic Forest biome in particular. That project only considered patches of 40 hectares or greater in area.

For a variety of reasons, in the great majority of forest surveys, small fragments are disregarded in the estimation of forest area. For example, in the past, limitations in spatial resolution and more recently, software and computer processing limitations represented problems. Meanwhile, geo-spatial technologies have evolved in recent years, allowing individual trees to be identified. From this innovation, a discussion has emerged about representation of socalled "Trees Outside Forests (TOFs)." A forest is defined according to the Global Forest Resources Assessments - FRA of FAO (2001) as land with a canopy cover (or its equivalent degree of coverage) greater than $10 \%$ and with a surface area greater than 0.5 hectare. The general forest definition mentioned above considers typical natural forests and forest plantations. According to FAO (2001), TOFs may be more frequent in some contexts, such as: areas of low or highly fragmented forest cover, as it is the case of the Atlantic Forest. It constitutes the main source of timber and non-timber products in many regions, though the trees may not be represented in the maps. TOFs in urban areas also provide important environmental and landscape services, and provide shade and higher quality housing in cities.

According Bierregaard Jr. et al. (1992), TOFs have no ability to protect biological diversity. However, these small remnants can act as stepping stones or small areas of habitat scattered throughout the matrix that for some species may facilitate dispersal between larger fragments (Ranta et al., 1998). They promote an increased heterogeneity in the matrix and act as refuges for species that require particular environments that occur only in those areas. Since fragments of larger sizes are more diverse, the species richness depends on the size of the fragment (Lefkovitch \& Faring, 1985).

According to FAO (2010), TOFs are located in so-called "other lands", especially farms and built up areas, both in rural and urban areas. A large number of TOFs consist of planted or domesticated trees. These include agroforestry systems, orchards and small groves (FAO 2001).

Another important initiative is France's National Forest Inventory (IFN) which has established a strategy whose aim is to classify TOFs more effectively. The goal is to use such information to update the data from the country's National Forest Inventory with a single national classification standard (MMA, 2011).

Herrera-Fernández (2003) developed a method for the classification and modeling of TOFs in Central American landscapes, combining data from remote sensing and Geographic Information Systems (GIS) and thus contributing important methodological tools for identifying TOFs using aerial photographs.

As mentioned by Kleinn (2000) and Herrera-Fernández (2003), TOF research efforts have been focused primarily at local scales, and only in recent years has this issue drawn attention from the Neotropics research community. Because of this lack of information on TOFs, Kleinn (2001) reported that a three-year project has been implemented in Central American countries (Costa Rica, Honduras and Guatemala).

The issue of TOFs in many municipalities has other implications beyond those already discussed. According to Viana et al. (1992), the distribution of size classes of fragments in the landscape is an important element in the development of strategies for biodiversity conservation. Over half of conservation reserves are less than 500 ha, which is insufficient for many plants and animals species.

Little attention has been paid in the scientific community to the theme of TOFs in Brazil, resulting most notably in the lack of official statistics and therefore global and local development of policies on the matter. Amidst increasing deforestation and environmental degradation in Brazil, there is evidence that TOFs are playing a significant role in the sustainability of local and regional environmental resources. These trees help alleviate pressures on native forest fragments and have an important environmental role to play, especially in urban ecosystems and in areas with high levels of fragmentation such as the northern region of Paraná State, a region with the lowest forest cover percentages of native forest in Brazil (Santos, 2005). In the case of Maringá TOFs contribute largely in terms of ensuring a minimum level of biodiversity and gene flow (Viana et al., 1992).

Thus, this study aimed at comparing the use of different satellite imageries - high resolution and medium resolution - and classification techniques to assess the contribution of TOFs in a region with a high concentration of green patches within a typically urban landscape, as well as native forest with low percent cover and which is highly fragmented. 


\section{MATERIALS AND METHODS}

\section{Location of the study area}

The study area is located in Maringá, northern Paraná State, at $23^{\circ} 25^{\prime} \mathrm{S}$ latitude and $51^{\circ} 57^{\prime} \mathrm{W}$ longitude (Figure 1).

According to Maack (1968), and using the physiognomic-Ecological System Classification of Brazilian vegetation, proposed by Veloso \& Goes-Filho (1982), the municipality of Maringá is encompassed in the phytogeographic region named Seasonal Semideciduous Forest (Leite \& Klein, 1990), belonging to the Atlantic Forest Biome (IBGE, 1992).

The climate in Maringá, according to the Köppen classification, is of the type Cfa subtropical, with hot summers, infrequent frosts and heavy rains in the summer.

Currently the region's forest cover is composed of small fragments located in some farms and areas adjacent to springs. However, most of the rivers have their riparian vegetation totally unprotected, in which grain crops or pasture extend to the riverbanks. Such a scenario has arisen in the context of occupation and use of highly valued land.

\section{Geo-spatial technologies applied}

The images used in this study were supplied by INPE (Brazilian National Institute for Space Research). The HRC sensor image of the CBERS 2B satellite was acquired on August 9, 2008. This sensor has a spatial resolution of 2.7 meters (high resolution) and operates in a single spectral range $(0.50$ to $0.80 \mathrm{~mm})$. The image covers an area of 729 $\mathrm{km}^{2}$ and is located on orbit 160, row (point) 126 . The CCD sensor CBERS 2B image was used for comparison, which was acquired on March 24, 2007. This sensor has a spatial resolution of 19.5 meters (medium resolution) and operates over five spectral bands (Nakamura \& Novo, 2005).

The first step of the present work was to geo-reference the images for the SAD-69 reference system using the ENVI 4.5 software. After that, it was carried out a classification of vegetated areas with characteristics of tree cover in the two images, using two distinct digital classification approaches. This requirement stems from the fact that the CCD image sensor produces images of medium spatial resolution, which allows only classifications based on the digital number (DN) of the pixels or reflectance values contained in it. The HRC image

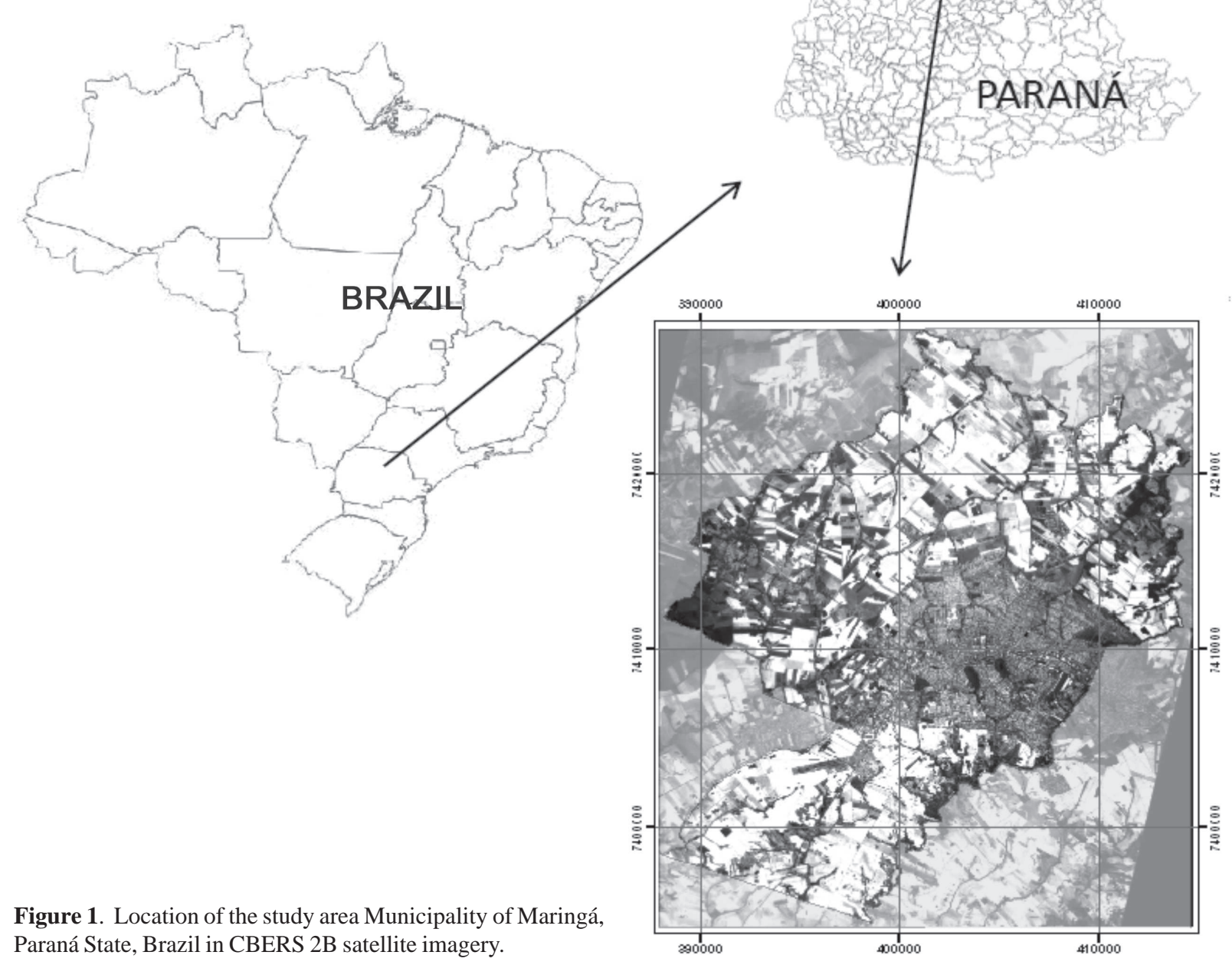

Rev. Ceres, Viçosa, v. 60, n.4, p. 480-488, jul/ago, 2013 
of high spatial resolution had to be processed using object oriented classification methods.

To classify the CBERS 2B HRC sensor images, the Ecognition software version 5.0 was used to perform automatic segmentation to create homogeneous regions (segments) prior to the classification procedure. Automatic classification in E-cognition tries to differentiate the class of interest, i.e., areas with the presence of forest-like green patches, using the interpretation indicators, or elements such as shape, texture and color. After automatic classification, a visual interpretation of all polygons was carried out to further identify forested areas, in order to improve the accuracy of the results generated. Finally, the images were compared against each other in order to ensure that all green patches were associated with the correct class. The gross results of the classification produced a shapefile (.shp) with polygons sorted for export to an ArcGIS 9.3 environment.

Classification of the CBERS CCD image was carried out initially using ENVI 4.5 software, color composition RGB: 3,4,2. Then, points were collected representing the class of interest (areas of tree vegetation). These samples of interest were then used in a supervised classification (Maximum Likelihood). This classification method considers the weights of the average distances and uses statistical parameters to perform the classification. The classified image was then converted into a vector file. In the raster, file polygons were dissolved and exploded by the process mentioned above.

In order to compare the results obtained from both images, the corresponding area of each polygon was calculated and divided into five classes: areas smaller than 500 square meters (Class 1), between 500 and 1,000 $\mathrm{m}^{2}$ (Class 2), between $1000 \mathrm{~m}^{2}$ and 5,000 $\mathrm{m}^{2}$ (Class 3), between $5,000 \mathrm{~m}^{2}$ and $10,000 \mathrm{~m}^{2}$ (Class 4), and greater than 10,000 $\mathrm{m}^{2}$ (Class 5). Later thematic maps were constructed with the results of the fragments to aid visualization, where Classes 1, 2 and 3 were considered TOFs and Classes 4 and 5 were considered forests.

Classes were also created from the polygons representing forests and TOFs. Shape in this step was expressed using the relationship between a forest fragment's area $\left(\mathrm{m}^{2}\right)$ and its perimeter $(\mathrm{m})$. The shape classes (area/perimeter) were divided as such: Class $1-\leq 5$, Class 2 - 5.01-10, Class 3-10.01-15 and Class $4->15$. The area/perimeter ratio is also known as the core/edge ratio.

According to Lang \& Blaschke (2009) the optimal shape in this respect is a circle, in which the interior area of the fragment is maximized with respect to the length of its edges. According to these authors, the current way of characterizing a fragment is to express its degree of deviation from this optimum form. In other words, the area/ perimeter ratio is compared with that of a circle of the same area. This ratio increases with the area of the fragment. Fragments with small areas and with perimeters that are relatively long have therefore low area/perimeter ratios.

\section{RESULTS AND DISCUSSION}

Mapping forests and TOFs with both types of satellite images showed quite different results in terms of green area, both on the perimeter of the municipality and the urban district of Maringá (Table 2). In the municipality as a whole, the green area mapped (forest + TOFs) with the high resolution image (HRC) totaled 4,513 hectares, while that mapped with the CCD sensor was of 1,876 hectares, or an area 2.4 times greater for HRC satellite mapping in comparison to CCD satellite mapping. In the urban area of the municipality, in relative terms, the difference was even greater, i.e., of 1,795 hectares and 407 hectares for HRC to $\mathrm{CCD}$, or an area that is 4.4 times greater for HRC.

These differences are even more pronounced when considering the numbers of polygons mapped. The numbers of polygons detected with the sensor HRC were 6.8 times greater $(18,495 \times 2,710$ units $)$, whereas the total area of the municipality and 9.4 times greater $(5,305 \times 563$ units), when taking into account only the urban perimeter. This demonstrates that higher resolution images allow better spatial capture of rather fragmented and small areas, as is usually the urban green areas.

The ability of the sensor HRC (higher spatial resolution) to detect TOFS is evident. The HRC sensor detected an area of 1,172 ha of TOFS in the municipality as a whole and 730 ha in the urban area, whereas the sensor CCR captured 216 ha in total area of the municipality and only 46 ha in the urban perimeter. It is important to note that in terms of numbers of polygons mapped, the HRC sensor, due to its higher spatial resolution, detected a number of TOFs polygons 7.7 times greater than that for the CCD sensor which were 2,283 $\mathrm{x} 17,499$ polygons in the municipality as a whole, and 4,680 x 468 polygons in the urban part of Maringá.

It was also observed that the TOFs size class distribution assumed a decreasing shape, both for the limit of the whole municipality as well as for the urban Maringá, i.e., a greater number of fragments in the smaller classes was recorded. The majority of TOFs concentrated on the class of less than $500 \mathrm{~m}^{2}$. On the contrary, there was a concentration of TOFs in the upper size class, i.e., 1,000 to 5,000 $\mathrm{m}^{2}$ (Figure 2). Viana (1990) compared landscapes with different fragmentation characteristics, reporting that most of the forested areas in that case $(58.4 \%)$ were large fragments (> 40 hectares) while the rest were small fragments ( $<10$ hectares). In this study similar results were obtained. 
Regarding the forest area, the larger fragments (over $10,000 \mathrm{~m}^{2}$ ) were predominant both in area and number of polygons. This pattern was observed for both the CCD satellite imagery as well as for HRC. However, it is important to note that both in area and number of polygons mapped, the HRC sensor, due to its higher spatial resolution, was able to detect a greater green area, especially because its capability to detect small woods, namely TOFs.

The forest fragments (over $5,000 \mathrm{~m}^{2}$ ) captured by the CCD sensor had a spatial distribution concentrated in some regions of the municipality, while TOFs presented a scattered pattern without clear differentiation between the extension of urban and rural areas (Figure 2). However, when analyzing the fragments of forest TOFs captured by the sensor HRC, another reality takes place. It was also indicated a large concentration of TOFs inside the urban area in contrast to the rural zone, since the TOFs occupy $9.96 \%$ of the territory's urban municipality (totaling $7,237.23 \mathrm{ha}$ ) and only $2.84 \%$ in rural area $(41,289.22 \mathrm{ha})$. This demonstrates that it is in the city that the small woods are concentrated. It could only be observed by using the HRC image. Another fact observable in the HRC image and invisible in the CCD is the presence of aligned woods representing the street and grove trees along the property borders and roads (Figure 3).

The shapes of forest fragments and TOFs were also analyzed by the area/perimeter ratio (Table 2). The lower

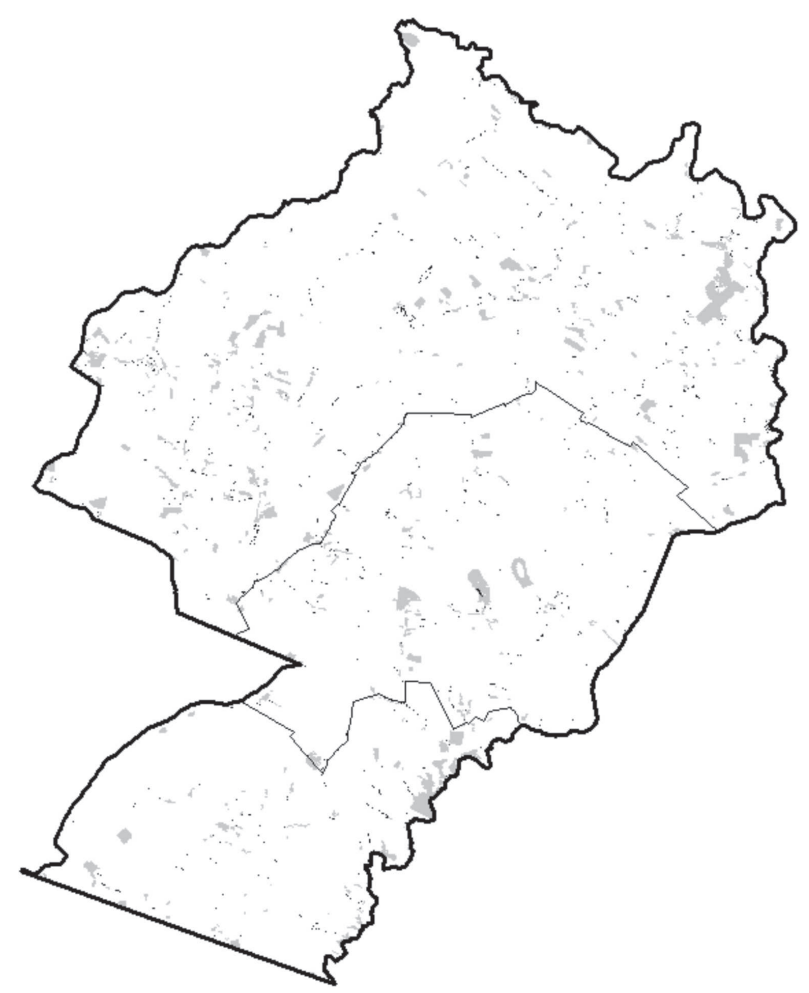

Figure 2. Municipality of Maringá, vegetation classification of CCD CBERS 2B sensor image. the area/perimeter ratio of polygons mapped the more elongated they are, and conversely, the higher the ratio, the more rounded they are. Forest fragments and TOFs existing in the municipality of Maringá are mostly elongated ones, which may represent a risk. Such elongated fragments are greatly affected by edge effects and have increased risk of collapse. In a study assessing biodiversity in forest fragments, Viana \& Pinheiro (1998) reported that $51.9 \%$ of fragments were considered elongated, $35 \%$ were very elongated, which are heavily affected by edge effects. This fact demonstrates that green area cover is not the only parameter to be taken into consideration but also the shape of the polygons shall be considered in defining conservation strategies in highly perturbed landscapes as the municipality of Maringá.

Heavy forest fragmentation is evident in most municipalities in the Southern and Southeastern Brazil, and notably in the northern Paraná, which has undergone vigorous agricultural development. Fragmentation has been due to anthropological agents such as the land-use structure of the region, laws governing land-use, and more importantly agriculture and livestock, the typical model of land use occupation. Present in a majority of municipalities, these small forest fragments represent a large expanse of tree cover and belong to the Atlantic Forest biome.

Almeida (2008) pointed out this fact during a mapping project of the Campos Gerais National Park, Paraná. In

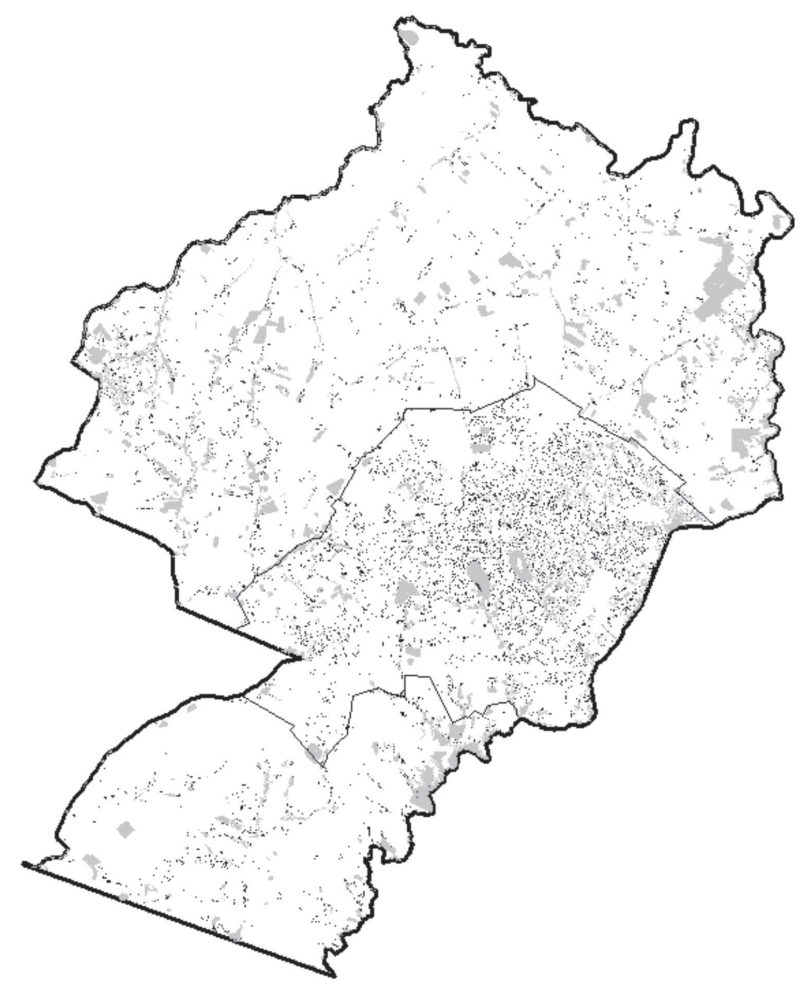

Figure 3. Municipality of Maringá, vegetation classification in HRC CBERS 2B sensor image. 
that study, it was estimated that $91.4 \%$ of forest patches were smaller than 5 ha. In the municipality of Ponte Nova, MG, Albanez (2000) highlighted a predominance of isolated fragments in the landscape, mostly consisting of forest patches smaller than 20 ha. Sanquetta et al. (2012), in a study of the Araucaria Forest (FOM) in Parana, using Landsat 5 images acquired in 1998, found that nearly 2.269 million hectares correspond to fragments $<50$ ha (i.e. $82.54 \%$ of the area of the FOM in Paraná). In this same study, only $13.77 \%$ of existing forest fragments were between 50 and 500 ha in size, while $3.69 \%$ corresponded to fragments $>500$ ha in size.

According to IBGE, Maringá had a population of 357,177 inhabitants in 2010. Considering only the urban perimeter of Maringá, we identified a total of 1,794.91 hectares of green areas in the high resolution image (HRC) and 406.58 hectares in the medium-resolution image (CCD). Maringá therefore had an average of $50.25 \mathrm{~m}^{2} /$ inhabitant based on the CBERS HRC sensor image and an average of $11.38 \mathrm{~m}^{2} /$ inhabitant for the CBERS CCD sensor image.

Quantification of urban forestry was accomplished through dependent and independent indicators of demography expressed, respectively, in terms of green area per inhabitant (IAV = Green Area Index) or percentage of land occupied by trees $(\mathrm{PAV}=$ Percent of Green Areas) (Oliveira, 1996). The existence of the index of $12 \mathrm{~m}^{2}$ of green area/inhabitant, which is considered as ideal, is rooted and widespread in Brazil and assigned

Table 1. Size and area of forest fragments located in the municipality of Maringá, mapped by using two different sensors

\begin{tabular}{|c|c|c|c|c|}
\hline \multirow{2}{*}{ Sensor } & \multirow{2}{*}{ Forest status } & \multicolumn{3}{|c|}{ Entire municipality } \\
\hline & & Forest fragment size & Number of polygons & Area (ha) \\
\hline \multirow{8}{*}{$\begin{array}{l}\text { CBERS 2B } \\
\text { CCD }\end{array}$} & \multirow{4}{*}{ TOF } & $<500$ & 1,296 & 48.26 \\
\hline & & $500-<1,000$ & 380 & 30.28 \\
\hline & & $1,000-<5,000$ & 607 & 137.53 \\
\hline & & Sub-total TOF & 2,283 & 216.07 \\
\hline & \multirow[t]{3}{*}{ Forests } & $5,000-10,000$ & 156 & 106.85 \\
\hline & & $>10,000$ & 271 & $1,552.74$ \\
\hline & & Sub-total Forests & 427 & $1,659.59$ \\
\hline & \multicolumn{2}{|l|}{ Total CCD sensor } & 2,710 & $1,875.66$ \\
\hline \multirow{8}{*}{$\begin{array}{l}\text { CBERS 2B } \\
\text { HRC }\end{array}$} & \multirow{4}{*}{ TOFs } & $<500$ & 11,055 & 266.42 \\
\hline & & $500-<1,000$ & 3,254 & 229.05 \\
\hline & & $1,000-<5,000$ & 3,190 & 676.23 \\
\hline & & Sub-total TOFs & 17,499 & $1,171.7$ \\
\hline & \multirow{3}{*}{ Forests } & $5,000-10,000$ & 465 & 326.41 \\
\hline & & $>10,000$ & 531 & $3,014.80$ \\
\hline & & Sub-total Forests & 996 & $3,341.21$ \\
\hline & Total HRC sensor & & 18,495 & $4,512.91$ \\
\hline \multirow{2}{*}{ Sensor } & \multirow{2}{*}{ Forest status } & \multicolumn{3}{|c|}{ Urban perimeter of the municipality } \\
\hline & & Forest fragment size & Number of polygons & Area (ha) \\
\hline \multirow{8}{*}{$\begin{array}{l}\text { CBERS 2B } \\
\text { CCD }\end{array}$} & \multirow{4}{*}{ TOFs } & $<500$ & 251 & 98.88 \\
\hline & & $500-<1.000$ & 85 & 67.82 \\
\hline & & $1.000-<5.000$ & 132 & 29.18 \\
\hline & & Sub-total TOFs & 468 & 45.85 \\
\hline & \multirow{3}{*}{ Forests } & $5.000-10.000$ & 27 & 18.87 \\
\hline & & $>10.000$ & 68 & 341.86 \\
\hline & & Sub-total Forests & 95 & 360.72 \\
\hline & Total CCD sensor & & 563 & 406.58 \\
\hline \multirow{8}{*}{$\begin{array}{l}\text { CBERS 2B } \\
\text { HRC }\end{array}$} & \multirow{4}{*}{ TOFs } & $<500$ & 700 & 172.61 \\
\hline & & $500-<1.000$ & 2,163 & 152.14 \\
\hline & & $1.000-<5.000$ & 1,997 & 405.16 \\
\hline & & Sub-total TOFs & 4,860 & 729.91 \\
\hline & \multirow{3}{*}{ Forests } & $5.000-10.000$ & 241 & 165.54 \\
\hline & & $>10.000$ & 204 & 899.46 \\
\hline & & Sub-total Forests & 445 & $1,065.00$ \\
\hline & Total HRC sensor & & 5,305 & $1,794.91$ \\
\hline
\end{tabular}


to the UN, WHO and FAO. This index is not known by those institutions and must be assumed as a reference to the categories of neighborhood parks and district/ sector areas useable for outdoor recreation (Cavalheiro \& Del Picchia, 1992). The Brazilian Society of Urban Forestry (SBAU) proposed as minimum index for public recreation green areas a value of $15 \mathrm{~m}^{2} /$ inhabitant (SBAU, 1996).

In this context, considering the mapping image with medium resolution imagery (CCD), Maringá was slightly below the lower limit of green area per inhabitant (11.65 $\mathrm{m}^{2}$ ), considering only the urban area of the city and the respective population $(349,120$ inhabitants). However, the interpretation would change completely when considering the mapping of green areas with the high resolution imagery (HRC), i.e., the green area per inhabitant was 3.42 times higher than indicated by $\operatorname{SBAU}\left(51.41 \mathrm{~m}^{2}\right)$.

The rural area of the municipality has a different situation, given that the rural population is only 7,997 people and, consequently, the green area per inhabitant is $1,837.05 \mathrm{~m}^{2}$ as mapped by the CCD satellite imagery and $3,398.77 \mathrm{~m}^{2}$ by the HRC. In the entire municipality, taking into consideration the total population of 357,117 inhabitants, the green areas per inhabitant are $52.52 \mathrm{~m}^{2}$ and $126.37 \mathrm{~m}^{2}$, respectively for CCD and HRC. These results demonstrate that it is very important to take into account and analyze separately the green areas in urban and rural zones when evaluating the forest cover in cities.

Satellite imagery technological advances have improved evaluation of land use and forest cover and helped to determine more accurately the individual green cover rate in urban centers. In Curitiba the green areas were evaluated in the year 2000 by medium-resolution imagery and the individual green rate was of $51.5 \mathrm{~m}^{2}$ per inhabitant. Another map of forest cover was produced in 2010 and the rate increased to $64.5 \mathrm{~m}^{2}$, by using the highresolution GeoEye imagery (SMMA, 2010). This growth in green cover was attributed to technological changes and not to increase in forest cover during the time period. This study shows the role of improvement in geotechnology to provide more reliable information on forest cover focused on the contribution of the small woods, namely TOFs, generally imperceptible by mediumresolution satellite imagery (Table 1).

The key features of the TOFs are the small size and of elongated shape, which implies in their low ecological resilience because of the greater edge effect (Table 2). Though small greens play an important environmental role in the cities, improving air quality, providing shade, beauty and so on, such woods suffer from pollution, vandalism, urban pests (as in Leal et al., 2006), and others. Saunders et al. (1991) have discussed the sustainability of these forest patches, which are considered as green islands,

Table 2. Comparison of area/perimeter index of fragments in the entire municipality and within the urban perimeter of Maringá

\begin{tabular}{|c|c|c|c|c|}
\hline \multirow{2}{*}{ Place } & \multirow{2}{*}{ Type } & \multirow{2}{*}{ Shape class } & \multicolumn{2}{|c|}{ Number of polygons } \\
\hline & & & HRC & CCD \\
\hline \multirow{10}{*}{ Entire municipality } & \multirow{4}{*}{ TOF } & $<5$ & 16,318 & 800 \\
\hline & & $5-10$ & 1,165 & 1,319 \\
\hline & & $10-15$ & 14 & 154 \\
\hline & & $>15$ & 0 & 0 \\
\hline & Total TOFs & 17,497 & 2,283 & \\
\hline & \multirow{4}{*}{ Forest } & $<5$ & 138 & 0 \\
\hline & & $5-10$ & 616 & 4 \\
\hline & & $10-15$ & 134 & 136 \\
\hline & & $>15$ & 108 & 287 \\
\hline & Total Forest & 996 & 427 & \\
\hline \multirow{10}{*}{ Urban perimeter } & \multirow{4}{*}{ TOF } & $<5$ & 10,657 & 151 \\
\hline & & $5-10$ & 586 & 286 \\
\hline & & $10-15$ & 2 & 31 \\
\hline & & $>15$ & 0 & 0 \\
\hline & Total TOFs & 11,245 & 468 & \\
\hline & \multirow{4}{*}{ Forest } & $<5$ & 90 & 0 \\
\hline & & $5-10$ & 300 & 0 \\
\hline & & $10-15$ & 35 & 27 \\
\hline & & $>15$ & 20 & 68 \\
\hline & Total Forest & & 445 & 95 \\
\hline
\end{tabular}


and stated their concern about theier conservation and ecological role. Further discussion on this issue is necessary, taking into consideration other variables in addition to land cover and area/perimeter ratio.

\section{CONCLUSIONS}

TOFs can be more reliably detected and quantified by using high-resolution satellite imagery such as CBERS2 HRC. Medium-resolution imagery such as CCD may underestimate the area of small forest patches and not provide their correct spatial distribution. Cost-benefit analysis must be considered in this context.

The municipality of Maringá's green cover (forests + TOFs) per inhabitant is above the limit considered by SBAU, if the HRC imagery is used. Otherwise it is a little under that limit. Anyhow, the urban population of Maringa city is provided by an expressive green cover $\left(>50 \mathrm{~m}^{2} /\right.$ inhabitant), responsible for providing various environmental services to it. The quality and the ecological resilience of these greens should be evaluated in future studies. This paper deals only with their quantification.

Most green patches of Maringá are small-sized $(<500$ $\mathrm{m}^{2}$ ) and scattered across the municipality. Almost $10 \%$ of the urban center of the municipality is represented by TOFs, in opposition to the rural zone, which has $1 \%$ of green cover represented by TOFs, as given by the HRC imagery mapping. Overall, TOFs represent $1.1 \%$ of the municipality and forest $5.5 \%$ of the total territory of the municipality, totaling $6.6 \%$. This forest cover is far from that required by the Brazilian legislation, which is $20 \%$ for the Atlantic Forest Biome.

\section{REFERENCES}

Albanez ACMP (2000) Caracterização dos fragmentos florestais a partir de estudos de ecologia da paisagem para o município de Ponte Nova, Minas Gerais. Dissertação de Mestrado. Universidade Federal de Viçosa, Viçosa. 160p.

Almeida CG (2008) Análise espacial dos fragmentos florestais na área do Parque Nacional dos Campos Gerais. Dissertação de Mestrado. Universidade Estadual de Ponta Grossa. Ponta Grossa. $72 \mathrm{p}$.

Bierregaard Jr, Lovejoy TE, Kapos V, Santos AA dos \& Hutchings RW (1992) The biological dynamics of tropical rain forest fragments: a prospective comparison of fragment and continuous forest. BioScience, 42:859-866.

Cavalheiro F \& Del Picchia PCD (1992) Áreas Verdes: conceitos, objetivos e diretrizes para o planejamento. In: Encontro Nacional sobre Arborização Urbana, 4.,Vitória, 1992. Anais. Vitória, PMV, p.29-38

FAO - Food and Agriculture Organization of the United Nations (2001) Global Forest Assessment FRA - 2000, Main report. FAO Forestry Paper 140. Rome. Italy. Disponível em: <http:// www.fao.org/forestry/32188/en/>. Acessado em: 06 de agosto de 2013.
FAO - Food and Agriculture Organization of the United Nations (2010) Global Forest Assessment 2000, Main report. FAO Forestry Paper 163. Rome. Italy. Disponível em: <http:// www.fao.org/forestry/fra/fra2010/en/>. Acessado em: 06 de agosto de 2013.

FAO - Food and Agriculture Organization of the United Nations (2011) State of the World's Forests. Rome. Italy. Access: Disponível em: <http://www.fao.org/docrep/013/i2000e/ i2000e00.htm>. Acessado em: 06 de agosto de 2013.

Herrera-Fernández B (2003) Classification and modeling of trees outside forest in Central American landscapes by combining remotely sensed data and GIS. Dissertação de Mestrado. AlbertLudwigs-Universität Freiburg, Freiburg. 247p.

IBGE (1992) Manual técnico da vegetação brasileira. Rio de Janeiro, Fundação Instituto Brasileiro de Geografia e Estatística IBGE. 92p.

Kleinn C (2000) On large-area inventory and assessment of trees outside forests. Unasylva, 51:3-10.

Kleinn C (2001) A cautionary note on the minimum crown cover criterion in forest definitions. Canadian Journal of Forestry Research, 31:350-356.

Lang S \& Blaschke T (2009) Análise da paisagem com SIG. Oficina de Textos, São Paulo. 424p.

Leal L, Bujokas WM \& Biondi D (2006) Análise da infestação de erva-de-passarinho na arborização de ruas de Curitiba, PR. Floresta, 36:323-330.

Lefkovitch LP \& Faring L (1985) Spatial characteristics of habitat patches and population survival. Ecological Modelling, 30:297308.

Leite P \& Klein RM (1990) Vegetação. In: IBGE. Geografia do Brasil: região Sul. v.2. Rio de Janeiro, Instituto Brasileiro de Geografia e Estatística - IBGE. p.113-150.

Maack R (1968) Geografia física do Estado do Paraná. Curitiba, Badep. 350p.

MMA - Ministério do Meio Ambiente (2011) Serviço Florestal Brasileiro. Inventário Florestal Nacional - IFN. Disponível em: <www.ifn.florestal.gov.br> Acessado em: 01 de agosto de 2011.

MMA/PROBIO - Ministério do Meio Ambiente (2007) Mapeamento de cobertura vegetal dos biomas brasileiros. Inserido no Projeto de Conservação e Utilização Sustentável da Diversidade - PROBIO. Disponível em: <http://homolog-w.mma.gov.br/ index.php?ido=publicacao.publicacoesPorSecretaria\&idEstrutura $=14>$. Acessado em: 06 de agosto de 2013 .

Nakamura J \& Novo E (2005) Mapeamento da mancha urbana utilizando imagens de média resolução: sensores CCD/CBERS2 e TM/Landsat5 - estudo de caso da cidade de Rio Branco-Acre. In: Anais do Simpósio Brasileiro de Sensoriamento Remoto. 12. Goiânia, INPE. 3.843-3. 850p.

Oliveira CH (1996) Planejamento ambiental na cidade de São Carlos (SP) com ênfase nas áreas públicas e áreas verdes: diagnóstico e proposta. Dissertação de Mestrado. Universidade Federal de São Carlos, São Carlos. 196p.

Ranta P, Blom T, Niemela J, Joensuu E \& Sitonen M (1998) The fragmented Atlantic rain forest of Brazil: size, shape an distribuition of forest fragments. Biodiversity and Conservation, 7:385-403.

Sanquetta CR, Dalla Corte AP \& Weber KS (2012) Fragmentação da floresta de Araucária no Estado do Paraná. Disponível em: <http://www.floresta.ufpr.br/fonline/m11.htm>. Acessado em: 06 de agosto de 2013. 
Santos MN dos (2005) Remanescentes florestais em áreas de preservação permanente no estado do Paraná. In: $13^{\circ}$ Evento de Iniciação Científica da UFPR. 2005. 1p.

Saunders DA, Hobbs RJ \& Margules CR (1991) Biological consequences of ecosystem fragmentation: a review. Conservation Biology, 5:18-34.

SBAU - Sociedade Brasileira de Arborização Urbana (1996) Carta de Londrina e Ibiporã. Boletim Informativo da SBAU, 3:1-3.

SMMA - Secretaria Municipal do Meio Ambiente (2010) Curitiba preserva e aumenta suas áreas verdes. Disponível em: <http:// www.curitiba.pr.gov.br/noticias/curitiba-preserva-e-aumentaareas-verdes/25478>. Acessado em: 25 de janeiro de 2012
Veloso HP \& Góes-Filho L (1982) Fitogeografia brasileira - classificação fisionômica ecológica da vegetação neotropical. Boletim Técnico Projeto RADAMBRASIL - Série Vegetação, 1:180

Viana VM (1990) Biologia e manejo de fragmentos florestais. In: Anais $6^{\circ}$ Congresso Florestal Brasileiro, Campos do Jordão. Anais, CFB. p.113-118.

Viana VM \& Pinheiro LAFV (1998) Conservação da biodiversidade em fragmentos florestais. Série Técnica IPEF, 32:25-42.

Viana VM, Tabanez AAJ \& Martins JLA (1992) Restauração e manejo de fragmentos florestais. In: Anais do 2 Congresso Nacional sobre Essências Nativas. São Paulo, Instituto Florestal de São Paulo. p.400-407. 